Original Research Article

\title{
A randomised double blind trial to compare the efficacy and tolerability of itopride hydrochloride versus domperidone in patients with non- ulcer dyspepsia: bloating predominant type
}

\author{
Gopesh Valoth, Sabeena Kizhedath*
}

Department of Pharmacology, Govt. Medical College, Thrissur, Thrissur, Kerala, India

Received: 12 October 2017 Accepted: 16 October 2017

*Correspondence to:

Dr. Sabeena Kizhedath, Email: drsabeenakizhedath@ gmail.com

Copyright: (C) the author(s), publisher and licensee Medip Academy. This is an openaccess article distributed under the terms of the Creative Commons Attribution NonCommercial License, which permits unrestricted noncommercial use, distribution, and reproduction in any medium, provided the original work is properly cited.

\begin{abstract}
Background: Non-ulcer dyspepsia is a treatment challenge due to multiple pathophysiological mechanisms and different symptoms. Several prokinetic drugs are tried without any unanimity regarding safety and efficacy. The objective of the study was to compare the efficacy and safety of Itopride and Domperidone in bloating predominant non ulcer dyspepsia patients.

Methods: Patients were randomly assigned to two groups (20 each) to receive either $50 \mathrm{mg}$ of Itopride three times daily or $10 \mathrm{mg}$ of Domperidone three times daily. Only patients with predominant bloating were considered and their baseline symptoms recorded. The symptoms were graded on a 4-point scale - the Global Symptom Score scale and the patients were reassessed at the end of 2 and 4 weeks. The relief of symptoms was also assessed at the end of 2 and 4 weeks on a 5-point scale - The Patients' Subjective Global Assessment of Relief scale.

Results: Both the drugs significantly produced symptomatic relief. Though Domperidone is marginally beneficial compared to Itopride after 4 weeks treatment in terms of improvement in symptom scores, the Subjective Global Assessment of relief did not show any significant improvement between the two drugs.

Conclusions: Treatment with Itopride was safe, well tolerated, resulted in good symptomatic relief, and was comparable in efficacy to Domperidone in relieving the symptoms of NUD. Hence it can be considered a good alternative for the treatment of non-ulcer dyspepsia.
\end{abstract}

Keywords: Itopride, Non-ulcer dyspepsia, Prokinetic drugs

\section{INTRODUCTION}

$60 \%$ of patients categorised as having non-ulcer dyspepsia or functional dyspepsia do not have a significant focal or structural lesion identified at upper endoscopy. ${ }^{1}$ The Rome III criteria states that functional dyspepsia must include one or more of the following symptoms - bothersome postprandial fullness, early satiation, epigastric pain, epigastric burning with no evidence of structural disease including at upper endoscopy, which is likely to explain the symptoms. These criteria should be fulfilled for at least 3 months with at least 6 months prior symptom onset. ${ }^{2}$ The categorisation of symptoms is ulcer like (burning sensation), dysmotility like (nausea, bloating, early satiety, anorexia) and unspecified. ${ }^{3}$ The pathophysiology of functional dyspepsia has been poorly understood. Some of the factors implicated in the pathophysiology of functional dyspepsia include motility disorders, non motility disorders (including Helicobacter pylori infection), psychosocial factors and certain drugs. ${ }^{4}$ The predominant symptom of functional dyspepsia determines the treatment. Prokinetic agents are beneficial in patients with predominant nausea and bloating who may be having motility dysfunction. Prokinetic agents like 
Metoclopramide, Domperidone and Cisapride decrease gastro-oesophageal reflux, improve gastric emptying and facilitate relief of dyspepsia. Metoclopramide is associated with a high incidence of adverse CNS effects. Domperidone produces gynaecomastia and galactorrhoea. ${ }^{5}$ Cisapride has potential to prolong QT interval and thus pre dispose to serious cardiac arrhythmias. ${ }^{6}$ Itopride hydrochloride, a newer prokinetic drug, has been reported to improve gastrointestinal motility by two actions, i.e. by inhibiting the action of dopamine on the D2 receptors on the post-synaptic cholinergic nerves and by stimulating the release of acetylcholine in the myenteric plexus. ${ }^{7-9}$ It also prevents the hydrolysis of the released acetylcholine by the enzyme acetylcholinesterase. $^{7}$

Acetylcholine (ACh) released from enteric nerve endings stimulates the contraction of smooth muscles through M3 receptors throughout the gut. The enzyme acetyl cholinesterase (AChE) hydrolyses the released acetyl choline, inactivates it and thus inhibits gastric motility. Besides ACh, dopamine present in the gastrointestinal tract has inhibitory effects on gastrointestinal motility, including reduction of lower oesophageal sphincter and intragastric pressure. These effects are due to suppression of ACh release from myenteric motor neurons and are mediated by D2 subtype of dopamine receptor. ${ }^{5}$ Itopride, by its dopamine D2 receptor antagonism, removes inhibitory effects on $\mathrm{ACh}$ release. The net result is an increase in acetylcholine concentration, which in turn promotes gastric motility, increases lower oesophageal sphincter pressure, accelerates gastric emptying and improves gastro-duodenal coordination. Cisapride has affinity for the 5-HT4 receptors in the heart that are implicated in the causation of cardiac adverse effects while Itopride has no affinity for these receptors. ${ }^{10}$

Itopride on oral administration is rapidly and extensively absorbed and peak serum concentrations are achieved within about 35 minutes after oral dosing. Food does not affect its absorption. It is metabolised in the liver to inactive metabolites by the enzyme flavin-containing moooxygenase. Plasma $t \frac{1}{2}$ is about 6 hours and it is excreted mainly by the kidneys as metabolites and unchanged drug.

Since Itopride is metabolised by the flavin-containing monooxygenase and not by the cytochrome P450 enzyme system, it is largely free of the risk of significant pharmacokinetic drug interaction with cytochrome P450 enzyme inhibitors such as macrolides and azole antifungals.

Usual daily dose of Itopride is $50 \mathrm{mg}$ orally three times a day before each major meal. ${ }^{11}$

Itopride is well tolerated with minor adverse drug reactions like diarrhoea, headache, abdominal pain etc. It has no significant effects on central nervous system and thus lacks extrapyramidal side effects and hyperprolactinemia seen with other prokinetic drugs like Metoclopramide and Domperidone. $^{12}$

\section{METHODS}

For this double blind randomised study, approved by the institutional ethics committee, patients were selected from the outpatient department of the Department of Gastroenterology, Government Medical College, Kozhikode. The study period was from January 2007 to January 2008.

Randomisation using Latin square design was done and patients were assigned to two groups to receive either Domperidone or Itopride. Complete history including personal information, duration of illness and other treatments taken were elicited. Investigations done included oesophagogastroduodenoscopy and ultrasound abdomen to rule out organic disease, complete hemogram, liver and renal function tests, blood glucose and electrocardiogram. 20 patients of either sex with symptoms of functional dyspepsia, bloating predominant type who fulfilled the inclusion criteria were included in the study. Written informed consent after thorough explanation of study procedure was obtained from all patients.

\section{Inclusion criteria}

- $\quad$ Patients above 18years and below 60years who satisfied Rome III criteria

- $\quad$ Patients with predominant bloating

\section{Exclusion criteria}

- Below 18years and above 60 years

- $\quad$ Endoscopic evidence of ulcer disease

- $\quad$ Severe oesophagitis

- History of chronic intake of NSAID's, anticoagulants and acid suppressants

- $\quad$ Pregnant and lactating women

Patients assigned to the Itopride group, received Itopride $50 \mathrm{mg}$ three times daily, 30 minutes before major meals. Patients in the Domperidone group received Domperidone $10 \mathrm{mg}$ three times daily, 30 minutes before major meals. The patients were told not to take any other medications related to their present condition.

Patients' baseline symptoms were recorded. A validated scoring system for non-ulcer dyspepsia, the 4-point scale (0-3) Global Symptom Score scale was used for grading the patients' symptoms. Intensity of symptoms was scored as 0- no symptoms, 1- mild symptoms, 2- moderate symptoms, 3- severe symptoms, while frequency of symptoms was graded as 0 - absent, $1-\geq 1$ to 2 days/week, 2 - $\geq 3$ to 4 days/week, 3 - $\geq 5$ days/week, both prior to treatment. The parameters considered were pain or discomfort, fullness, bloating, early satiety, nausea and burning. In accordance with the inclusion criteria, only patients with predominant bloating were considered. Each 
parameter (symptom) was scored for intensity and frequency and total scores added up for the Global Symptom Score. Patients were reviewed at the end of 2 weeks and 4 weeks during which their symptom scores were re-assessed.

Relief of symptoms was assessed at the end of 2 weeks and 4weeks on a 5-point scale(1-5) - The Patients' Subjective Global Assessment of Relief scale and scored as 1- marked or complete relief of symptoms , 2 - moderate relief of symptoms, 3 - slight relief of symptoms, 4 - no relief of symptoms and 5 - worsening of symptoms. ECG was done before and after treatment to check for any increase in the QT interval. The patients were instructed to report immediately any untoward effects due to the drugs.

\section{Statistical analysis}

Paired and Independent samples T-test were done for the data. Results were tabulated and the significance was expressed as $\mathrm{p}$ value $<0.05$ (Significant) and $<0.001$ (Highly Significant).

\section{RESULTS}

A total of 40 patients with bloating predominant functional dyspepsia who fulfilled inclusion criteria were selected from outpatient department of the Department of Gastroenterology, Government Medical College, Kozhikode. They were randomly assigned into two groups to receive either Itopride or Domperidone. The collected data was analysed.

The baseline parameters are comparable in both groups (Table 1).

The comparison of global symptom scores prior to treatment and after 2 weeks treatment with Domperidone, shows a highly significant $(\mathrm{p}<0.001)$ reduction of global scores at 2 weeks.

Table 1: Comparison of baseline parameters.

\begin{tabular}{|lll|}
\hline Parameter & Itopride & Domperidone \\
\hline Mean age (years) & $39.10 \pm 11.42 S D$ & $37.25 \pm 9.96 S D$ \\
\hline Sex (M:F) & $1: 3$ & $1: 4$ \\
\hline $\begin{array}{l}\text { Mean duration of } \\
\text { illness (yrs) }\end{array}$ & 4.57 & 3.62 \\
\hline Symptom scores & \\
\hline Prior to treatment & 18 & 14.25 \\
\hline After 2 weeks & 10.65 & 8.75 \\
\hline After 4 weeks & 8.05 & 4.15 \\
\hline
\end{tabular}

The values were expressed as the mean of the intensity and frequency of pain or discomfort, fullness, bloating, early satiety, nausea and burning, and at two weeks the reduction of intensity and frequency of symptoms as shown by the decrease in mean total score was highly significant (Table 2).
Table 2: Global symptom score analysis after 2 weeks.

\begin{tabular}{|c|c|c|c|c|c|}
\hline Domperidone & Mean & $\mathbf{N}$ & $\begin{array}{l}\text { Std. } \\
\text { devia- } \\
\text { tion }\end{array}$ & $\begin{array}{l}\text { Std. } \\
\text { error } \\
\text { mean }\end{array}$ & $\begin{array}{l}\text { Sig. } \\
\text { (p } \\
\text { value) }\end{array}$ \\
\hline $\begin{array}{l}\text { Symptom score } \\
\text { before } R_{x}\end{array}$ & 14.25 & 20 & 3.81 & 0.85 & \multirow{2}{*}{0.000} \\
\hline $\begin{array}{l}\text { Symptom score } \\
\text { after } 2 \text { weeks }\end{array}$ & 8.75 & 20 & 4.35 & 0.97 & \\
\hline
\end{tabular}

Similarly the comparison of global symptom scores prior to treatment and after treatment with Domperidone, shows a highly significant $(\mathrm{p}<0.001)$ reduction of global scores at 4 weeks The values were expressed as the mean of the intensity and frequency of pain or discomfort, fullness, bloating, early satiety, nausea and burning, and at four weeks the reduction of intensity and frequency of symptoms as shown by the decrease in mean total score was highly significant (Table 3).

Table 3: Global symptom score analysis after 4 weeks.

\begin{tabular}{|llllll|}
\hline Domperidone & Mean & $\mathbf{N}$ & $\begin{array}{l}\text { Std. } \\
\text { devia- } \\
\text { tion }\end{array}$ & $\begin{array}{l}\text { Std. } \\
\text { error } \\
\text { mean }\end{array}$ & $\begin{array}{l}\text { Sig. } \\
(\mathbf{p} \\
\text { value })\end{array}$ \\
\hline $\begin{array}{l}\text { Symptom } \\
\text { score before } \\
\mathrm{R}_{\mathrm{x}}\end{array}$ & 14.25 & 20 & 3.81 & 0.85 & \multirow{2}{*}{0.000} \\
\hline $\begin{array}{l}\text { Symptom } \\
\text { score after } \mathrm{R}_{\mathrm{x}}\end{array}$ & 4.15 & 20 & 4.69 & 1.05 & \\
\hline
\end{tabular}

The comparison of subjective global assessment scores at 2 weeks and 4 weeks also shows as per patients' assessment, a highly significant $(\mathrm{p}<0.001)$ reduction of mean scores with Domperidone at 4 weeks compared to scores at 2 weeks (Table 4$)$.

Table 4: SGA score analysis at 2 weeks and 4 weeks.

\begin{tabular}{|llllll|}
\hline Domperidone & Mean & $\mathbf{N}$ & $\begin{array}{l}\text { Std. } \\
\text { Devia- } \\
\text { tion }\end{array}$ & $\begin{array}{l}\text { Std. } \\
\text { error } \\
\text { mean }\end{array}$ & $\begin{array}{l}\text { Sig. } \\
(\mathbf{p} \\
\text { value })\end{array}$ \\
\hline $\begin{array}{l}\text { SGA at 2 } \\
\text { weeks }\end{array}$ & 2.70 & 20 & 0.66 & 0.15 & 0.000 \\
\hline $\begin{array}{l}\text { SGA at 4 } \\
\text { weeks }\end{array}$ & 1.90 & 20 & 0.91 & 0.20 & \\
\hline
\end{tabular}

There is however no significant change in QT interval with Domperidone at 4 weeks compared to the value prior to treatment (Table 5).

\section{Table 5: QT interval analysis prior to treatment and} at 4 weeks.

\begin{tabular}{|c|c|c|c|c|c|}
\hline Domperidone & Mean & $\mathbf{N}$ & $\begin{array}{l}\text { Std. } \\
\text { Devia- } \\
\text { tion }\end{array}$ & $\begin{array}{l}\text { Std. } \\
\text { error } \\
\text { mean }\end{array}$ & $\begin{array}{l}\text { Sig. } \\
\text { (p } \\
\text { value) }\end{array}$ \\
\hline $\begin{array}{l}\text { QT interval } \\
\text { baseline }\end{array}$ & 0.3420 & $\begin{array}{l}2 \\
0\end{array}$ & $\begin{array}{l}4.396 \mathrm{E} \\
-02\end{array}$ & $\begin{array}{l}9.830 \\
\text { E-03 }\end{array}$ & \multirow{2}{*}{0.148} \\
\hline $\begin{array}{l}\text { QT interval at } 4 \\
\text { weeks }\end{array}$ & 0.3500 & $\begin{array}{l}2 \\
0\end{array}$ & $\begin{array}{l}4.425 \mathrm{E} \\
-02\end{array}$ & $\begin{array}{l}9.894 \\
\text { E-03 }\end{array}$ & \\
\hline
\end{tabular}


The comparison of global symptom scores prior to treatment and after 2 weeks treatment with Itopride shows highly significant $(\mathrm{p}<0.001)$ reduction in global symptom scores at 2 weeks. The values were expressed as the mean of the intensity and frequency of pain or discomfort, fullness, bloating, early satiety, nausea and burning, and at two weeks, the reduction of intensity and frequency of symptoms as shown by the decrease in mean total score was highly significant (Table 6).

Table 6: Global symptom score analysis after 2 weeks.

\begin{tabular}{|lcclll|}
\hline Itopride & Mean & $\mathbf{N}$ & $\begin{array}{l}\text { Std. } \\
\text { Deviation }\end{array}$ & $\begin{array}{l}\text { Std. } \\
\text { Error } \\
\text { Mean }\end{array}$ & $\begin{array}{l}\text { Sig. } \\
(\mathbf{p} \\
\text { value })\end{array}$ \\
\hline $\begin{array}{l}\text { Symptom } \\
\text { score } \\
\text { before } \mathrm{R}_{\mathrm{x}}\end{array}$ & 18.00 & 20 & 3.70 & 0.83 & \\
\hline $\begin{array}{l}\text { Symptom } \\
\text { score after } \\
2 \text { weeks }\end{array}$ & 10.65 & 20 & 4.59 & 1.03 & 0.000 \\
\hline
\end{tabular}

Similarly the comparison of global symptom scores prior to treatment and after treatment (4 weeks) with Itopride shows a highly significant $(\mathrm{p}<0.001)$ reduction of global scores at 4 weeks. The values were expressed as the mean of the intensity and frequency of pain or discomfort, fullness, bloating, early satiety, nausea and burning, and at four weeks the reduction of intensity and frequency of symptoms as shown by the decrease in mean total score was highly significant (Table 7).

The comparison of subjective global assessment scores at 2 weeks and 4 weeks also shows, as per patients' assessment, a highly significant $(\mathrm{p}<0.001)$ reduction of mean scores with Itopride at 4 weeks (Table 8).
Table 7: Global symptom score analysis after 4 weeks.

\begin{tabular}{|c|c|c|c|c|c|}
\hline Itopride & Mean & $\mathbf{N}$ & $\begin{array}{l}\text { Std. } \\
\text { deviation }\end{array}$ & $\begin{array}{l}\text { Std. } \\
\text { error } \\
\text { mean }\end{array}$ & $\begin{array}{l}\text { Sig. } \\
(p \\
\text { value) }\end{array}$ \\
\hline $\begin{array}{l}\text { Symptom } \\
\text { score } \\
\text { before } \mathrm{R}_{\mathrm{x}}\end{array}$ & 18.00 & 20 & 3.70 & 0.83 & \multirow{2}{*}{0.000} \\
\hline $\begin{array}{l}\text { Symptom } \\
\text { score after } \\
\mathrm{R}_{\mathrm{x}}\end{array}$ & 8.05 & 20 & 4.15 & 0.93 & \\
\hline
\end{tabular}

Table 8: SGA score analysis at 2 weeks and 4 weeks.

\begin{tabular}{|llllll|}
\hline Itopride & Mean & $\mathbf{N}$ & $\begin{array}{l}\text { Std. } \\
\text { deviation }\end{array}$ & $\begin{array}{l}\text { Std. } \\
\text { error } \\
\text { mean }\end{array}$ & $\begin{array}{l}\text { Sig. } \\
(\mathbf{p} \\
\text { value })\end{array}$ \\
\hline $\begin{array}{l}\text { SGA at } 2 \\
\text { weeks }\end{array}$ & 2.80 & 20 & 0.83 & 0.19 & \multirow{2}{*}{0.000} \\
\cline { 1 - 3 } $\begin{array}{l}\text { SGA at } 4 \\
\text { weeks }\end{array}$ & 2.30 & 20 & 0.73 & 0.16 & \\
\hline
\end{tabular}

Table 9: QT interval analysis prior to treatment and at 4 weeks.

\begin{tabular}{|llllll|}
\hline Itopride & Mean & $\mathbf{N}$ & $\begin{array}{l}\text { Std. } \\
\text { deviation }\end{array}$ & $\begin{array}{l}\text { Std. } \\
\text { error } \\
\text { mean }\end{array}$ & $\begin{array}{l}\text { Sig. } \\
(\mathbf{p} \\
\text { value })\end{array}$ \\
\hline $\begin{array}{l}\text { QT } \\
\text { interval } \\
\text { base } \\
\text { line }\end{array}$ & 0.2740 & 20 & $3.952 \mathrm{E}-02$ & $\begin{array}{l}8.838 \mathrm{E}- \\
03\end{array}$ & \\
\hline $\begin{array}{l}\text { QT } \\
\text { interval } \\
\text { at } 4 \\
\text { weeks }\end{array}$ & 0.2640 & 20 & $2.383 \mathrm{E}-02$ & $\begin{array}{l}5.351 \mathrm{E}- \\
03\end{array}$ \\
\hline
\end{tabular}

Table 10: Itopride versus domperidone - global symptom score analysis.

\begin{tabular}{|c|c|c|c|c|c|c|}
\hline & Group & $\mathbf{N}$ & Mean & Std. deviation & Std. error mean & Sig. (p value) \\
\hline \multirow{2}{*}{ Before treatment } & Itopride & 20 & 18.00 & 3.70 & 0.83 & \multirow{2}{*}{0.300} \\
\hline & Domperidone & 20 & 14.25 & 3.81 & 0.85 & \\
\hline \multirow{2}{*}{ After 2 weeks } & Itopride & 20 & 10.65 & 5.59 & 1.03 & \multirow{2}{*}{0.187} \\
\hline & Domperidone & 20 & 8.75 & 4.35 & 0.97 & \\
\hline \multirow{2}{*}{ After 4 weeks } & Itopride & 20 & 8.05 & 4.15 & 0.93 & \multirow{2}{*}{0.008} \\
\hline & Domperidone & 20 & 4.15 & 4.69 & 1.05 & \\
\hline
\end{tabular}

Again there is no significant change in QT interval with Itopride at 4 weeks compared to the value prior to treatment (Table 9).

Comparing the efficacy of Itopride against Domperidone in reducing symptom scores at 2 weeks and 4 weeks, Domperidone produced significant $(\mathrm{p}<0.05)$ reduction in symptoms at 4 weeks compared to Itopride. The values were expressed as the mean of the intensity and frequency of pain or discomfort, fullness, bloating, early satiety, nausea and burning, and at four weeks the reduction of intensity and frequency of symptoms by Domperidone as compared to Itopride was significant (Table 10).

Comparing the efficacy of Itopride against Domperidone in reducing the patients' Subjective Global Assessment of 
relief score at 2 weeks and 4 weeks, though Domperidone appears better, the change was not significant $(\mathrm{p}>0.05)$ (Table 11).

\section{Table 11: Itopride versus domperidone - SGA analysis.}

\begin{tabular}{|lllllll|}
\hline SGA & Group & $\mathbf{N}$ & Mean & $\begin{array}{l}\text { Std. } \\
\text { devi- } \\
\text { ation }\end{array}$ & $\begin{array}{l}\text { Std. } \\
\text { Error } \\
\text { mean }\end{array}$ & $\begin{array}{l}\text { Sig. } \\
(\mathbf{p} \\
\text { value })\end{array}$ \\
\hline 2 & Itopride & 20 & 2.80 & 0.83 & 0.19 & 0.676 \\
\cline { 2 - 6 } weeks & Domperidone & 20 & 2.70 & 0.66 & 0.15 & \\
\hline 4 & Itopride & 20 & 2.30 & 0.73 & 0.16 & \multirow{2}{*}{0.671} \\
\cline { 2 - 6 } weeks & Domperidone & 20 & 1.90 & 0.91 & 0.20 & \\
\hline
\end{tabular}

Two patients in the Itopride group developed diarrhoea while one patient developed burning chest pain. In the Domperidone group one patient developed diarrhoea and one patient developed galactorrhoea at the end of 4 weeks which subsided on stopping the drug.

\section{DISCUSSION}

Functional dyspepsia is a poorly understood gastrointestinal disorder presenting with a variety of symptoms like nausea, bloating, early satiety, anorexia, epigastric pain or epigastric burning without evidence of organic disease at upper endoscopy. ${ }^{13-15}$

Although several treatment options are available, in patients with predominant nausea and bloating, who may be having motility dysfunction, prokinetic agents are the best drugs. The currently available prokinetic agents like Metoclopramide, Domperidone and Mosapride have undesirable adverse effects. ${ }^{5}$

Itopride inhibits the action of Dopamine on D2 receptors and stimulates the release of acetylcholine besides preventing the destruction of acetylcholine by the enzyme acetylcholinesterase. Various studies comparing the efficacy of Itopride in functional dyspepsia have proved it to be efficacious.

The present study, a randomised double blind trial to compare the efficacy and tolerability of Itopride versus Domperidone in bloating predominant functional dyspepsia found that Domperidone produced significant reduction in symptoms at 4 weeks compared to Itopride $(\mathrm{p}<0.05)$. However on comparing the reduction in Subjective Global Assessment of relief score at 2 weeks and 4 weeks by the two drugs, there was no significant difference between them. Assessment of tolerability showed that two patients in the Itopride group developed diarrhoea while one patient developed burning chest pain. In the Domperidone group one patient developed diarrhoea and one patient developed galactorrhoea at the end of 4 weeks which subsided on stopping the drug.
The present study results are comparable to the study by Sawant P et al. wherein Itopride was found to be safe, well tolerated and comparable in efficacy to Domperidone. ${ }^{16}$

\section{CONCLUSION}

Treatment with Itopride produced good symptomatic relief in patients with bloating predominant type of non ulcer dyspepsia. It was well tolerated and comparable in efficacy to Domperidone in relieving symptoms and was without cardiac adverse effects.

\section{Funding: No funding sources}

Conflict of interest: None declared

Ethical approval: The study was approved by the Institutional Ethics Committee

\section{REFERENCES}

1. Tack J, Bisschops R, Sarnelli G. Pathophysiology and treatment of functional dyspepsia. Gastroenterology 2004;127(4):1239-55.

2. Lin C. The Rome III criteria for the functional GI disorders ,2006. Available at: http://www.medscape.com.View Article/533460.Accessed 21August 2007.

3. Talley NJ, Stanghellini V, Heading RC. Functional gastroduodenal disorders. GUT. 1999;45(2):1137-42.

4. McQuaid KR. Dyspepsia. In: Feldman M, Friedman LS, Sleisenger MH, eds.Sleisenger and Fordtran's Gastrointestinal and Liver Diseases: Pathophysiology, Diagnosis, Management. $8^{\text {th }}$ Ed. Philadelphia, Pa: Saunders; 2002:121-138.

5. Pasricha PJ. Prokinetic agents, antiemetics and agents used in irritable bowel syndrome. In: Hardman JG, Limbird LE,eds. Goodman and Gilman's The Pharmacological Basis of Therapeutics. $10^{\text {th }} \mathrm{Ed}$, New York, McGraw -Hill; 2001:1021-1036.

6. Wysowski DK, Corken A, Gallo-Torres H. Postmarketing reports of QT prolongation and ventricular arrhythmia in association with Cisapride and Food and Drug Administration regulatory actions. American Journal of Gastroenterology. 2001;96:169870.

7. Iwanga Y, Miyashita N, Mizutani F. Stimulatory effect ofN- [4-[2-(dimethylamino) ethoxy] benzyl]-34-dimethoxybenzamide hydrochloride (HSR-803) on normal and delayed gastrointestinal propulsion. Jpn J Pharmacol. 1991;56:261-9.

8. Iwanga Y, Miyashita N, Morikawa K. Novel water soluble dopamine-2-antagonist with anticholinesterase activity in gastrointestinal propulsion. Gastroenterol. 1993;99:401-8.

9. Iwanga $\mathrm{Y}$, Miyashita N, Saito T. Gastroprokinetic effect of a new benzamide derivative Itopride and its action mechanism in conscious dogs. Jpn J Pharmacol. 1996;71:129-37.

10. Kakiuchi M, Saito T, Ohara N. Pharmacological evaluation of Itopride hydrochloride with drug- 
induced arrhythmias. Jpn Pharmacol Ther 1997;25:811-7.

11. Mushiroda T, Douya R, Takahara E. The involvement of flavin containing monooxygenase but not CYP3A4 in metabolism of Itopride hydrochloride, a gastro prokinetic agent: comparison with Cisapride and Mosapride citrate. Drug Meta Dispos. 2000;28:12317.

12. Banka NH. Role of prokinetics in dyspepsia. Gastroenterology Today. 2003;7:1-4.

13. Thomson AB, Barkun AN, Armstrong D. The prevalence of clinically significant endoscopic findings in patients with uninvestigated dyspepsia: The Canadian Adult Dyspepsia Empirical treatment Prompt Endoscopy (CADET-PE) study. Aliment Pharmacol Ther. 2003;17:1481.

14. The Danish Dyspepsia Study group: Value of the unaided clinical diagnosis in dyspeptic patients in primary care. American Journal of Gastroenterology. 2001;96:1417.

15. Talley N, Silverstein MD, Agreus L. AGA technical review: Evaluation of dyspepsia. Gastroenterology. 1998;114:582.

16. Sawant P, Das HS, Desai H. A Comparative evaluation of efficacy and tolerability of Itopride hydrochloride and Domperidone in patients with nonulcer dyspepsia. J Assoc Physicians India. 2004;52:626-8.

Cite this article as: Valoth G, Kizhedath S. A randomised double blind trial to compare the efficacy and tolerability of itopride hydrochloride versus domperidone in patients with non-ulcer dyspepsia: bloating predominant type. Int $\mathrm{J}$ Basic Clin Pharmacol 2017;6:2601-6. 